\title{
The SLCO1B1*15 haplotype associated with lower clinical outcome in Indonesian tuberculosis patients
}

\author{
Sunarto Ang ${ }^{1 *}$, Akhmad Kharis Nugroho ${ }^{2}$, Ahmad Hamim Sadewa ${ }^{3}$, Lukman Hakim ${ }^{4}$, \\ Mustofa $^{5}$ \\ 'Department of Internal Medicine, Abdul Wahab Sjahranie General Hospital, Samarinda, \\ ${ }^{2}$ Department of Pharmaceutics, Faculty of Pharmacy, ${ }^{3}$ Department of Biochemistry, \\ Faculty of Medicine, ${ }^{4}$ Department of Pharmacology and Clinical Pharmacy, Faculty \\ of Pharmacy, ${ }^{5}$ Department of Pharmacology and Therapeutic, Faculty of Medicine, \\ Universitas Gadjah Mada, Yogyakarta, Indonesia
}

DOI: http://dx.doi.org/10.19106/JMedSci005001201806

\section{ABSTRACT}

Rifampin is one of first-line drugs for the treatment of tuberculosis. In Indonesia nearly all tuberculosis patients show lower rifampin plasma concentration's possibly due to genetics. Rifampin is a substrate of the organic anion-transporting polypeptide 1B1 (OATP 1B1) encoded by the solute carrier organic anion transporter family member 1B1 (SLCO1B1). This study aimed to identify haplotype polymorphisms of tuberculosis drug transporters with an impact on clinical outcome in tuberculosis patients. Thirty-six patients from I.A Moeis District Hospital, Samarinda, East Kalimantan were involved in the study. Buffy coat from patient blood samples were tested for SLCO1B1 and SLCO1B3 polymorphisms by RFLP and ARMS PCR, whereas the clinical outcome was examined based on the sputum conversion histopathology residuals. The frequency of patients with $S \angle C O 1 B 1 * 15$ haplotype was $63.9 \%$. The $S \angle C O 1 B 1 * 15$ haplotype was associated with susceptibility to failure of clinical outcome $(p=0.005 ; R R=4.52 ; 95 \% C l: 1.22-16.64)$. The OATP1B1 15 haplotype revealed that the failure of clinical outcome was markedly increased compared to the three other haplotypes. These results suggest that the SLCO1B1*15 haplotype is an important predisposing factor for lower clinical outcome. Our data indicate that individualized treatment should be considered for Indonesian tuberculosis patients based on genetics characteristics of patients.

\section{ABSTRAK}

Rifampin merupakan salah satu obat utama untuk pengobatan tuberkulosis. Di Indonesia hampir semua penderita tuberkulosis menunjukkan konsentrasi rifampisin yang rendah yang kemungkinan karena faktor genetik. Rifampin merupakan substrat dari Organic anion-transporting polypeptide 1B1 yang dikode oleh gen Solute carrier organic anion transporter family member 1B1 (SLCO1B1). Penelitian ini bertujuan mengidentifikasi polimorfisme haplotipe transporter obat tuberkulosis dan hubungannya dengan luaran klinis penderita tuberkulosis. Sebanyak 36 penderita tuberkulosis dari RSUD I.A. Moeis, Samarinda, Kalimantan Timur terlibat dalam penelitian. Buffy coat sampel darah pasien diperiksa polimorfisme SLCO1B1 dan SLCO1B3 menggunakan PCR RFLP dan ARMS, sedangkan luaran klinis ditentukan berdasarkan konversi sputum dan hasil histopatologi. Frekuensi penderita dengan SLCO1B1*15 haplotipe sebanyak 63,9\%. SLCO1B1*15

\footnotetext{
${ }^{*}$ corresponding author : sunarto.ang1967@gmail.com
} 
Sunarto Ang et al., The SLCO1B1*15 haplotype associated with lower clinical outcome in Indonesian tuberculosis patients

haplotipe berhubungan dengan risiko kegagalan pengobatan hasil klinis $(p=0,005$; $\mathrm{RR}=4,52 ; 95 \% \mathrm{Cl}: 1,22-16,64)$. OATP1B1*15 haplotipe mengungkapkan bahwa kegagalan hasil klinis lebih tinggi dibandingkan ketiga haplotipe lainnya. Hasil penelitian ini terbukti SLCO1B1*15 haplotipe merupakan faktor predisposisi penting untuk memprediksi rendahnya luaran klinis. Disarankan agar pengobatan penderita tuberkulosis secara individu harus dipertimbangkan berdasarkan karakteristik genetik pasien.

Keyword: $S L C O 1 B 1 * 15$ haplotipe - tuberculosis - clinical outcome

\section{INTRODUCTION}

Tuberculosis (TB) is one of the major mortality risks in the world and is caused by Mycobacterium tuberculosis, which infects over 2 billion people, or almost one third of the world's 7 billion population. ${ }^{1}$ Indonesia has the second ranked largest number of cases in the world. Rifampin (RIF) is a key component in the treatment regimen and due to its efficacy is used as a primary anti-TB drug. ${ }^{1,2}$ The development of resistance to RIF is found to be related to RIF concentrations. ${ }^{3}$ Despite this concern, there is limited RIF dosing information to ensure optimal outcome. A number of studies have shown interindividual RIF pharmacokinetic variability ${ }^{4-6}$ and this genetic diversity may support the need to increase RIF dosage in Indonesian TB patients. ${ }^{7}$ Recent research has explored a link between genetics and treatment efficacy ${ }^{4,8}$ and the present study is the first to assess genetic diversity in Indonesian patients with confirmed diagnosis of pulmonary TB (PTB) and extrapulmonary TB (EPTB). In evaluating clinical outcomes, we examined major single-nucleotide polymorphisms (SNPs) of SLCO1B1 and SLCO1B3. Considering genetic aspects potentially influential on the reduced levels of RIF concentration's.

As a substrate of organic anion transporting polypeptides OATP1B1 (coded by SLCO1B1) and OATP1B3 (coded by SLCO1B3), ${ }^{9,10} \mathrm{SNP}$ research has associated the SLCO1B1 SNP
$\mathrm{C}_{463 \mathrm{~A}^{4}}$ and $\mathrm{rs} 4149032^{8}$ with reduced RIF exposure. Other recent studies showed that it did not influence the exposure and involves genetic variability ${ }^{11,12}$ while presently there are no studies of the major SNPs in Indonesian patients. This study aimed to determine the major SNPs which may influence efficacy of treatment among Indonesian PTB and EPTB patients and the second objective of the study was to evaluate their potential impact on the clinical outcome. Applying our assessment of genetic variability to clinical outcomes, the data may assist in therapeutic-drug treatment schedules and monitoring in PTB and EPTB patients in Indonesia.

\section{MATERIALS AND METHODS}

\section{Participants}

This study used a cohort study, where we analyzed 36 patients with PTB and EPTB who had received an oral anti-TB regimen at I.A. Moeis District Hospital, Samarinda, Indonesia in 2014. The study participants had sputum smear-positive pulmonary TB or extrapulmonary TB from tissue biopsy which was definite if histopathology results showed the typical necrotizing granuloma containing macrophages, lymphocytes and Langhans giant cells. Caseous necrosis can be sometimes found in the central part of the granuloma, including: lymph node TB, gastrointestinal TB, skin and soft tissue TB. Directly observed daily administration of treatment involved 
fixed-dose combination tablets (4FDC) with $150 \mathrm{mg}$ rifampin, $75 \mathrm{mg}$ isoniazid, 400 $\mathrm{mg}$ pyrazinamide and $275 \mathrm{mg}$ ethambutol. Following Indonesian standard tuberculosis treatment guidelines, patients $<38 \mathrm{~kg}$ received 2 tablets daily, those weighing 38 to $54 \mathrm{~kg}$ received 3 tablets, 55 to $70 \mathrm{~kg}$ received 4 tablets daily and patients $>71 \mathrm{~kg}$ received 5 tablets once daily. ${ }^{13}$ All patients received TB drugs from the same manufacturer. The following variables were available: sex, age, BMI, ethnic and clinical outcome, including sputum smear and post-treatment biopsy. The study has been approved by the Medical and Health Research Ethics Committee, Faculty of Medicine, Public Health and Nursing Universitas Gadjah Mada, Yogyakarta.

\section{Genotyping}

We extracted blood sample DNA from the buffy coat by using the GeneJET Genomic DNA Purification Kit \#K0722 (Thermo Fisher Scientific). We used the restriction fragment length polymorphism (RFLP) PCR for allelic discrimination in genotyping [SLCO1B1 rs2306283 (c.388 $\quad \mathrm{A}>\mathrm{G}), \quad$ SLCO1B1 rs11045818 (c.411 G>A), SLCO1B3 rs4149117 (c.334 $\mathrm{T}>\mathrm{G})$ and $\mathrm{rs} 7311358$ (c.699 G>A)] and the amplification refractory mutation system (ARMS) PCR [SLCO1B1 rs4149056 (c.521T $>$ C) ]. Primers were sourced from Integrated DNA Technologies (Coralville, Iowa, USA). Two samples of each genotype were directly sequenced to confirm and validate our genotyping results with Applied Biosystems 3730 DNA Analyzer. The protocol to prepare the PCR involved an initial denaturation step at $94^{\circ} \mathrm{C}$ for 5 to $7 \mathrm{~min}$, followed by 35 to 40 cycles of denaturation at $94^{\circ} \mathrm{C}$ for 30 to $60 \mathrm{~s}$ and then annealing temperature for 30 to $60 \mathrm{~s}$ and extension at $72^{\circ} \mathrm{C}$ for 30 to $60 \mathrm{~s}$ (TABLE 1). All PCR amplifications were conducted in a PCRengine apparatus $\mathrm{T} 100^{\mathrm{TM}}$ Thermal Cycler (Bio-Rad Life Science, USA). Restriction enzymes were sourced from Thermo Fisher Scientific. TABLE 1 below identifies the following SNPs based on allele frequencies previously shown to be involved in drug transport from the blood to the liver.

TABLE 1. Primers and PCR conditions used for genotyping of gene polymorphisms

\begin{tabular}{|c|c|c|c|c|c|}
\hline Polymorphism & Primer sequence $\left(5^{\prime} \rightarrow 3^{\prime}\right)^{a}$ & $\begin{array}{l}\text { Fragment } \\
\text { size (bp) }\end{array}$ & $\begin{array}{c}\text { Annealing } \\
\text { temperature } \\
\left({ }^{\circ} \mathrm{C}\right)\end{array}$ & $\begin{array}{c}\text { Amplification } \\
\text { cycles }\end{array}$ & $\begin{array}{l}\text { Restriction } \\
\text { enzyme }\end{array}$ \\
\hline$S L C O 1 B 1$ & F: GCAAATAAAGGGGAATATTTCTC & 274 & 46 & 37 & TaqI \\
\hline $\begin{array}{l}\text { rs2306283 and } \\
\text { rs11045818 }\end{array}$ & R: AGAGATGTAATTAAATGTATAC & & & & \\
\hline SLCO1B1 & F:AAGTAGTTAAATTTGTAATAGAAATGC & 260 & 48 & 35 & - \\
\hline \multirow[t]{3}{*}{ rs4149056 } & WT: GGGTCATACATGTGGATATAAGT & & & & \\
\hline & MT: AAGCATATTACCCATGAACG & & & & \\
\hline & R: GTAGACAAAGGGAAAGTGATCATA & & & & \\
\hline$S L C O 1 B 3$ & F: GAAGGTACAATGTCTTGGGC & 339 & 58 & 35 & AluI \\
\hline rs4149117 & R: CTCTCAAAAGGTAACTGCCC & & & & \\
\hline SLCO1B3 & F: ATGATTACATTCCCTGGATC & 303 & 56.3 & 40 & RsaI \\
\hline rs7311358 & R: ACTATCATGGTACCTTGTTC & & & & \\
\hline
\end{tabular}

${ }^{a}$ F: Forward primer; R: reverse primer; WT: wild-type; MT: mutant-type 
Sunarto Ang et al., The SLCO1B1*15 haplotype associated with lower clinical outcome in Indonesian tuberculosis patients

For SLCO1B1 rs2306283 and rs11045818, the PCR product was digested using $5 \mathrm{U}$ of restriction enzyme at $65^{\circ} \mathrm{C}$ overnight. The products of restriction were placed in 3\% agarose gel for electrophoresis and visualized by ethidium bromide staining. The restriction pattern consist of four distinct zones (154, 142,132 and $119 \mathrm{bp}$ ), each representative for $388 \mathrm{~A}>\mathrm{G}$ and $411 \mathrm{G}>\mathrm{A}$ wild-type and mutant alleles. This pattern in descending order stands for the two polymorphisms as follows: $154 \mathrm{bp}$ for 411A, $142 \mathrm{bp}$ for 388A, $132 \mathrm{bp}$ for $411 \mathrm{G}$ and $119 \mathrm{bp}$ for $388 \mathrm{G} .^{14}$

For SLCO1B1 rs4149056, the tetra primer used in ARMS-PCR with slight modifications. ${ }^{15}$ Because the restriction endonuclease was unnecessary, the PCR products were detected by means of $2 \%$ agarose gel with electrophoresis and by ethidium bromide staining. This pattern stands for the polymorphisms as follows: wild-type (260 and $179 \mathrm{bp}$ ); heterozygote (260, 123 and $179 \mathrm{bp}$ ) and mutant (260 and $123 \mathrm{bp}$ ). For SLCO1B3 rs4149117, the PCR product was digested using $5 \mathrm{U}$ of restriction enzyme at $37^{\circ} \mathrm{C}$ overnight. The products of restriction were placed in 2\% agarose gel for electrophoresis and visualized by ethidium bromide staining. The restriction pattern consists of two distinct zones (253 and $213 \mathrm{bp}$ ). This pattern stands for the polymorphisms as follows: wild-type (253 bp); heterozygote (253 and $213 \mathrm{bp}$ ) and mutant (213 bp). ${ }^{16}$

For SLCO1B3 rs7311358, the PCR product was digested using $5 \mathrm{U}$ of restriction enzyme. The restriction pattern consists of two distinct zones (242 and $275 \mathrm{bp}$ ). This pattern stands for the polymorphisms as follows: wild-type (242 bp); heterozygote (242 and $275 \mathrm{bp}$ ) and mutant (275 bp). ${ }^{16}$ In follow-up we assessed the clinical outcome with sputum conversion (PTB) or tissues through fine needle aspiration biopsy (EPTB). We compared the pre and post-treatment results. We categorized success if sputum conversion or lesions typically disappeared and improved histopathologically after the initiation of treatment. The failure of treatment outcome meant sputum conversion or lesions did not disappear and did not improve histopathologically.

\section{Statistical analysis}

Data were presented as median or percentage. The association between genetics polymorphisms of SLCO and clinical outcome was analysed using Fisher's exact test. A $p$-value $<0.05$ was considered as significant. 


\section{RESULTS}

Thirty-six tuberculosis patients including 24 (66.7\%) PTB and 12 (33.3\%) EPTB were involved in this study. The demographics and genetics of the patients are presented in TABLE 2.

TABLE 2. Demographics and genotype description of cohort

\begin{tabular}{|c|c|c|c|}
\hline \multirow{2}{*}{\multicolumn{2}{|c|}{ Demographics }} & \multicolumn{2}{|c|}{ Median (range) or $n(\%)$} \\
\hline & & Male $22(61.11 \%)$ & Female $14(38.89 \%)$ \\
\hline Age (years) & & $42(23-60)$ & $39(16-65)$ \\
\hline Body weight (kg) & & $48(37-65)$ & $46.5(35-98)$ \\
\hline Height (m) & & $1.56(1.42-1.72)$ & $1.51(1.4-1.63)$ \\
\hline BMI $\left(\mathrm{kg} / \mathrm{m}^{2}\right)$ & & $20.1(16-27.7)$ & $21.4(15.4-38.3)$ \\
\hline Genetics & $\begin{array}{c}\text { Homozygous wild type, } \\
n(\%)\end{array}$ & $\begin{array}{c}\text { Heterozygous mutant type, } \\
n(\%)\end{array}$ & $\begin{array}{c}\text { Homozygous mutant type, } \\
n(\%)\end{array}$ \\
\hline SLCO1B1 rs11045818 & $31(86.11)$ & $5(13.89)$ & $0(0)$ \\
\hline$S L C O 1 B 1$ rs 2306283 & $0(0)$ & $10(27.78)$ & $26(72.22)$ \\
\hline SLCO1B1 rs4149056 & $3(8.33)$ & $32(88.89)$ & $1(2.78)$ \\
\hline SLCO1B3 rs4149117 & $2(5.55)$ & $14(38.89)$ & $20(55.56)$ \\
\hline$S L C O 1 B 3$ rs7311358 & $2(5.55)$ & $14(38.89)$ & $20(55.56)$ \\
\hline Haplotype & $n(\%)$ & Male, $n(\%)$ & Female, $n(\%)$ \\
\hline$S L C O 1 B 1 * 1 \mathrm{a}$ & $9(25)$ & $3(13.6)$ & $6(42.8)$ \\
\hline$S L C O 1 B 1 * 1 \mathrm{~b}$ & $35(97.2)$ & $22(100)$ & $13(92.3)$ \\
\hline$S L C O 1 B 1 * 5$ & $8(22.2)$ & $3(13.6)$ & $5(35.7)$ \\
\hline$S L C O 1 B 1 * 15$ & $23(63.9)$ & $11(50)$ & $12(85.7)$ \\
\hline
\end{tabular}

BMI: body mass index

The two most common SLCO1B1 SNPs (c.521T $>$ C and c.388A $>$ G) form four functionally distinct haplotypes: SLCO1B ${ }^{*} 1 \mathrm{a}$ (c.388A-c.521T, as reference haplotype), ${ }^{*} 1 \mathrm{~b}$ (c.388G-c.521T), *5 (c.388A-c.521C), and *15 (c.388G-c.521C). ${ }^{17-19}$ All polymorphisms were in Hardy-Weinberg equilibrium. The patients carrying at least one $* 15$ haplotype had a significantly increased risk for failure of treatment ( $p=0.005$ ), and subjects carrying the *15 haplotype had a 4.52-fold significantly elevated risk (95\% CI: 1.22-16.64) for failure of treatment. The SLCO1B1 rs11045818 was not analyzed due to its insignificance. The SLCO1B3 rs4149117 and rs7311358 polymorphisms did not have a statistically significant association with clinical outcome. We evaluated the differences in the haplotypeassociated effects on clinical outcome, which also were associated with differences in overall drug exposures (TABLE 3). 
Sunarto Ang et al., The SLCO1B1*15 haplotype associated with lower clinical outcome in Indonesian tuberculosis patients

TABLE 3. Response treatment based on genotype of TB patients $(n=36)$

\begin{tabular}{|c|c|c|c|c|}
\hline Genetics & $\begin{array}{c}\text { Success } \\
18(50 \%)\end{array}$ & $\begin{array}{c}\text { Failure } \\
18(50 \%)\end{array}$ & $p^{a}$ & $\mathbf{R R}(\mathbf{C I})^{\mathbf{b}}$ \\
\hline \multicolumn{5}{|l|}{ SLCO1B1 rs11045818 } \\
\hline GG & $15(41.7)$ & $16(44.4)$ & 1 & $0.775(0.25-2.39)$ \\
\hline GA & $3(8.3)$ & $2(5.6)$ & & \\
\hline AA & $0(0)$ & $0(0)$ & & \\
\hline \multicolumn{5}{|l|}{ SLCO1B1 rs2306283 } \\
\hline AA & $0(0)$ & $0(0)$ & 0.711 & - \\
\hline $\mathrm{AG}$ & $6(16.7)$ & $4(11.1)$ & & \\
\hline GG & $12(33.3)$ & $14(38.9)$ & & \\
\hline \multicolumn{5}{|l|}{ SLCO1B1 rs4149056 } \\
\hline $\mathrm{TT}$ & $2(5.5)$ & $1(2.8)$ & 0.603 & $1.54(0.30-7.92)$ \\
\hline $\mathrm{TC}$ & $15(41.7)$ & $17(47.2)$ & & \\
\hline $\mathrm{CC}$ & $1(2.8)$ & $0(0)$ & & \\
\hline \multicolumn{5}{|l|}{ SLCO1B3 rs4149117 } \\
\hline $\mathrm{TT}$ & $1(2.8)$ & $1(2.8)$ & 0.389 & $1(0.24-4.16)$ \\
\hline TG & $9(25)$ & $5(13.9)$ & & \\
\hline GG & $8(22.2)$ & $12(33.3)$ & & \\
\hline \multicolumn{5}{|l|}{ SLCO1B3 rs7311358 } \\
\hline $\mathrm{GG}$ & $1(2.8)$ & $1(2.8)$ & 0.389 & $1(0.24-4.16)$ \\
\hline GA & $9(25)$ & $5(13.9)$ & & \\
\hline AA & $8(22.2)$ & $12(33.3)$ & & \\
\hline \multicolumn{5}{|l|}{ Haplotype } \\
\hline c*1a $(388 \mathrm{~A} 521 \mathrm{~T})$ & 5 & 4 & 1 & $0.85(0.38-1.93)$ \\
\hline Other $* 1 \mathrm{a}$ & 13 & 14 & & \\
\hline $\mathrm{d} * 1 \mathrm{~b}(388 \mathrm{G} 521 \mathrm{~T})$ & 17 & 18 & 1 & - \\
\hline Other $* 1 \mathrm{~b}$ & 1 & 0 & & \\
\hline e*5 (388A521C) & 5 & 3 & 0.691 & $0.7(0.27-1.82)$ \\
\hline Other $* 5$ & 13 & 15 & & \\
\hline \multicolumn{5}{|l|}{ Haplotype groups } \\
\hline$-/-^{\mathrm{f}}$ & 11 & 2 & 0.005 & $4.52(1.22-16.64)$ \\
\hline$* 15 /-\mathrm{g}$ & 7 & 16 & & \\
\hline
\end{tabular}

${ }^{\mathrm{a} D a t a}$ are calculated using Fisher's exact test, ${ }^{\mathrm{b}}$ Risk ratio (Confidence Interval), ${ }^{\mathrm{c} *} 1 \mathrm{a}$ including $\left(* 1 \mathrm{a} /{ }^{*} 1 \mathrm{a},{ }^{*} 1 \mathrm{a} /{ }^{*} 1 \mathrm{~b}\right.$, $* 1 \mathrm{a} / * 15),{ }^{*} 1 \mathrm{~b}$ including $(* 1 \mathrm{~b} / * 1 \mathrm{~b}, * 1 \mathrm{a} / * 1 \mathrm{~b}, * 1 \mathrm{~b} / * 5, * 1 \mathrm{~b} / * 15),{ }^{*} * 5$ including $(* 1 \mathrm{~b} / * 5, * 1 \mathrm{a} / * 5, * 5 / * 5, * 5 / * 15),{ }^{\mathrm{f}}-/-$ including $(* 1 \mathrm{a} / * 1 \mathrm{a}, * 1 \mathrm{a} / * 1 \mathrm{~b}, * 1 \mathrm{~b} / * 1 \mathrm{~b}),{ }^{\mathrm{g} *} 15 /$ - indicates at least one $* 15$ allele $(* 1 \mathrm{~b} / * 15, * 1 \mathrm{a} / * 15, * 5 / * 15, * 15 / * 15)$.

\section{DISCUSSION}

Our study is the first in an Indonesian population to demonstrate that the SLCO1B1*15 haplotype can be associated with clinical outcome in patients with PTB and EPTB. Among the TB patients with lower RIF concentrations, ${ }^{20}$ we found this haplotype in $63.9 \%$, which is consistent with other studies of Indonesian patients. ${ }^{7}$ The lower RIF concentrations observed for Indonesians could be partially accounted for by the $S L C O 1 B 1^{*} 15$ haplotype. The high frequency of the $S L C O 1 B 1^{*} 15$ haplotype suggests that the haplotype can help to predict the clinical outcome for certain Indonesian populations. We investigated the effect of major haplotypes 
of drug transporters and related demographics on clinical outcome. We analyzed factors that could influence outcome of treatment in Indonesian PTB and EPTB patients. The variable - SLCO1B1*15 haplotype -was found to significantly affect the clinical outcome. We identified a significant link between SLCO1B1*15 haplotype and treatment, ${ }^{21-23}$ which could be explained by decreased hepatocellular uptake due to reduced drug transporter activity mediated by OATP $1 \mathrm{~B} 1 .^{24}$

Some studies examining both peak plasma concentration $\left(C_{\max }\right)$ and area under the curve (AUC) of RIF exposure have demonstrated definite correlation with clinical outcomes. ${ }^{25,26}$ Related to genetic diversity, advances in genotyping of SLCO1B1 rs11045818 have identified a synonymous variant $(411 \mathrm{G}>\mathrm{A})$ (https://www.ncbi.nlm.nih.gov/clinvar/ variation/307936/). For SLCO1B3, we did not observe any significant pharmacogenetic effects due to its limited impact. Our findings confirmed there is some effect of the SLCO1B1*15 haplotype on RIF exposure and treatment outcome, but presently it is not well understood. Although c.521T $>\mathrm{C}$ and c.388A $>\mathrm{G}$ SNPs appear to be insignificant, the $S L C O 1 B 1 * 15$ haplotype (which includes both SNPs) has been consistently associated with reduced OATP1B1 transport activity. ${ }^{21}$

There were also some limitations in our study. For example, all of our investigated patients were coadministered isoniazid, ethambutol and pyrazinamide with RIF, and thus any confounding effects of medicines could not be fully eliminated in this study. Nonetheless, the present results indicate that OATP1B1 variants may be involved in the failure of clinical outcome and provide a new potential failure risk for patients with this disease.

\section{CONCLUSION}

Our final results show the $S L C O 1 B 1 * 15$ haplotype exists in the Indonesian population and is associated with the effect of reducing the clinical outcome. This link was examined in an Indonesian population with PTB and EPTB. Because of high frequency of the SLCO1B1*15 haplotype compared to non*15 haplotype, our data suggests that this genotype may provide some prediction for clinical outcome and therefore, specialized diagnosis and treatment should be considered for select Indonesian patients discriminatively based on individual genetic assessment. Actual clinical studies are needed to evaluate and confirm the variability of genotypes for the general population.

\section{ACKNOWLEDGMENTS}

We are grateful to the volunteers participating in this study. We also thank the staff of the I.A. Moeis District Hospital, Faculty of Medicine, Public Health and Nursing and Faculty of Pharmacy, Universitas Gadjah Mada who gave us valuable assistance during the study.

\section{REFERENCES}

1. Diacon AH, Patientia RF, Venter A, van Helden PD, Smith PJ, McIlleron $\mathrm{H}$, et al. Early bactericidal activity of highdose rifampin in patients with pulmonary tuberculosis evidenced by positive sputum smears. Antimicrob Agents Chemother 2007; 51(8):2994-96.

http://dx.doi.org/10.1128/AAC.01474-06

2. Weiner M, Benator D, Burman W, Peloquin CA, Khan A, Vernon A, et al. Association between acquired rifamycin resistance and the pharmacokinetics of rifabutin and isoniazid among patients with HIV and tuberculosis. Clin Infect Dis 2005; 40(10):1481-91. http://dx.doi.org/10.1086/429321 
Sunarto Ang et al., The SLCO1B1*15 haplotype associated with lower clinical outcome in Indonesian tuberculosis patients

3. Gumbo T, Louie A, Deziel MR, Liu W, Parsons LM, Salfinger M, et al. Concentrationdependent mycobacterium tuberculosis killing and prevention of resistance by rifampin. Antimicrob Agents Chemother 2007; 51(11):3781-8.

http://dx.doi.org/10.1128/AAC.01533-06

4. Weiner M, Peloquin C, Burman W, Luo CC, Engle M, Prihoda TJ, et al. Effects of tuberculosis, race, and human gene SLCO1B1 polymorphisms on rifampin concentrations. Antimicrob Agents Chemother 2010; 54(10):4192-200. http://dx.doi.org/10.1128/AAC.00353-10

5. Pasipanodya JG, Srivastava S, Gumbo T. Meta-analysis of clinical studies supports the pharmacokinetic variability hypothesis for acquired drug resistance and failure of antituberculosis therapy. Clin Infect Dis 2012; 55(2):169-77. http://dx.doi.org/10.1093/cid/cis353

6. Srivastava S, Pasipanodya JG, Meek C, Leff R, Gumbo T. Multidrug-resistant tuberculosis not due to noncompliance but to betweenpatient pharmacokinetic variability. J Infect Dis 2011; 204(12):1951-9. http://dx.doi.org/10.1093/infdis/jir658

7. Ruslami R, Nijland HM, Alisjahbana B, Parwati I, van Crevel R, Aarnoutse RE. Pharmacokinetics and tolerability of a higher rifampin dose versus the standard dose in pulmonary tuberculosis patients. Antimicrob Agents Chemother 2007; 51(7):2546-51. http://dx.doi.org/10.1128/AAC.01550-06

8. Chigutsa E, Visser ME, Swart EC, Denti P, Pushpakom S, Egan D, et al. The SLCO1B1 rs4149032 polymorphism is highly prevalent in South Africans and is associated with reduced rifampin concentrations: dosing implications. Antimicrob Agents Chemother 2011; 55(9):4122-7.

http://dx.doi.org/10.1128/AAC.01833-10
9. Vavricka SR, Van Montfoort J, Ha HR, Meier PJ, Fattinger K. Interactions of rifamycin SV and rifampicin with organic anion uptake systems of human liver. Hepatology 2002; 36(1):164-72.

http://dx.doi.org/10.1053/jhep.2002.34133

10. Tamai I, Nozawa T, Koshida M, Nezu J, Sai Y, Tsuji A. Functional characterization of human organic anion transporting polypeptide B (OATP-B) in comparison with liver-specific OATP-C. Pharm Res 2001; 18(9):1262-9. http://dx.doi.org/10.1023/A:1013077609227

11. Ramesh K, Hemanth, Kannan T, Vijayalakshmi R, Sudha V, Manohar Nesakumar S, et al. SLCO1B1 gene polymorphisms do not influence plasma rifampicin concentrations in a South Indian population. Int J Tuberc Lung Dis 2016; 20(9):1231-5. http://dx.doi.org/10.5588/ijtld.15.1007

12. Seng KY, Hee KH, Soon GH, Chew N, Khoo $\mathrm{SH}$, Lee LS. Population pharmacokinetics of rifampicin and 25-deacetyl-rifampicin in healthy Asian adults. J Antimicrob Chemother 2015; 70(12):3298-306. http://dx.doi.org/10.1093/jac/dkv268

13. Ministry of Health RoI. Indonesian Tuberculosis Treatment Guidelines [Internet]. 2014 [cited 2017 Jan 3]. Available from: http://www.tbindonesia.or.id/2015/02/11/ buku-bpnptb-2014

14. Giannakopoulou E, Ragia G, Kolovou V, Tavridou A, Tselepis AD, Elisaf M, et al. No impact of SLCO1B1 521T $>$ C, 388A $>$ G and $411 \mathrm{G}>\mathrm{A}$ polymorphisms on response to statin therapy in the Greek population. Mol Biol Rep 2014; 41(7):4631-8. http://dx.doi.org/10.1007/s11033-014-3334-z

15. Xu LY, He YJ, Zhang W, Deng S, Li Q, Zhang WX, et al. Organic anion transporting polypeptide-1B1 haplotypes in Chinese patients. Acta Pharmacol Sin 2007; 28(10):1693-7. 
http://dx.doi.org/10.1111/j.17457254.2007.00643.x

16. Tsujimoto M, Hirata S, Dan Y, Ohtani H, Sawada Y. Polymorphisms and linkage disequilibrium of the OATP8 (OATP1B3) gene in Japanese subjects. Drug Metab Pharmacokinet 2006; 21(2):165-9. http://dx.doi.org/10.2133/dmpk.21.165

17. Tirona RG, Leake BF, Merino G, Kim RB. Polymorphisms in OATP-C: identification of multiple allelic variants associated with altered transport activity among Europeanand African-Americans. J Biol Chem 2001; 276(38):35669-75.

http://dx.doi.org/10.1074/jbc.M103792200

18. Nozawa T, Nakajima M, Tamai I, Noda K, Nezu J, Sai Y, et al. Genetic polymorphisms of human organic anion transporters OATP-C (SLC21A6) and OATP-B (SLC21A9): allele frequencies in the Japanese population and functional analysis. J Pharmacol Exp Ther 2002; 302(2):804-13.

http://dx.doi.org/10.2133/dmpk.21.165

19. Niemi M, Schaeffeler E, Lang T, Fromm MF, Neuvonen M, Kyrklund C, et al. High plasma pravastatin concentrations are associated with single nucleotide polymorphisms and haplotypes of organic anion transporting polypeptide-C (OATP-C, SLCO1B1). Pharmacogenetics 2004; 14(7):429-40. http://dx.doi.org/10.2133/dmpk.21.165

20. van Crevel R, Alisjahbana B, de Lange WC, Borst F, Danusantoso H, van der Meer JW, et al. Low plasma concentrations of rifampicin in tuberculosis patients in Indonesia. Int $\mathrm{J}$ Tuberc Lung Dis 2002; 6(6):497-502. https://doi.org/10.5588/09640569513002

21. Kameyama Y, Yamashita K, Kobayashi K, Hosokawa M, Chiba K. Functional characterization of SLCO1B1 (OATP-C) variants, SLCO1B1*5, SLCO1B1*15 and SLCO1B1*15+C1007G, by using transient expression systems of HeLa and HEK293 cells. Pharmacogenet Genomics 2005; 15(7):513-22.

ht tps://doi.org/10.1097/01. fpc.0000170913.73780.5f

22. Nozawa T, Minami H, Sugiura S, Tsuji A, Tamai I. Role of organic anion transporter OATP1B1 (OATP-C) in hepatic uptake of irinotecan and its active metabolite, 7-ethyl10-hydroxycamptothecin: in vitro evidence and effect of single nucleotide polymorphisms. Drug Metab Dispos 2005; 33(3):434-9. http://dx.doi.org/10.1124/dmd.104.001909

23. Iwai M, Suzuki H, Ieiri I, Otsubo K, Sugiyama Y. Functional analysis of single nucleotide polymorphisms of hepatic organic anion transporter OATP1B1 (OATP-C). Pharmacogenetics 2004; 14(11):749-57. https://doi.org/10.1097/00008571200411000-00006

24. Tirona RG, Leake BF, Wolkoff AW, Kim RB. Human organic anion transporting polypeptide-C (SLC21A6) is a major determinant of rifampin-mediated pregnane $\mathrm{X}$ receptor activation. J Pharmacol Exp Ther 2003; 304(1):223-8. http://dx.doi.org/10.1124/jpet.102.043026

25. Pasipanodya JG, Mcllleron H, Burger A, Wash PA, Smith P, Gumbo T. Serum drug concentrations predictive of pulmonary tuberculosis outcomes. J Infect Dis 2013; 208(9):1464-73. http://dx.doi.org/10.1093/infdis/jit352

26. Jayaram R, Gaonkar S, Kaur P, Suresh BL, Mahesh BN, Jayashree R, et al. Pharmacokinetics-pharmacodynamics of rifampin in an aerosol infection model of tuberculosis. Antimicrob Agents Chemother 2003; 47(7):2118-24. https://doi.org/10.1128/AAC.47.7.21182124.2003 